\title{
Building a Political Constituency for Urban School Reform
}

\section{Citation}

Warren, Mark. 2011. Building a political constituency for urban school reform. Urban Education 46, no. 3:484-512.

\section{Published Version}

doi:10.1177/0042085910377441

\section{Permanent link}

http://nrs.harvard.edu/urn-3:HUL.InstRepos:4871463

\section{Terms of Use}

This article was downloaded from Harvard University's DASH repository, and is made available under the terms and conditions applicable to Other Posted Material, as set forth at http:// nrs.harvard.edu/urn-3:HUL.InstRepos:dash.current.terms-of-use\#LAA

\section{Share Your Story}

The Harvard community has made this article openly available.

Please share how this access benefits you. Submit a story.

Accessibility 


\section{Building a Political Constituency for Urban School Reform}

Mark R. Warren

Associate Professor of Education

Harvard University

Mark R. Warren, Harvard Graduate School of Education, 301 Nichols House, Cambridge, MA 02138, mark_warren@harvard.edu 


\title{
Building a Political Constituency for Urban School Reform
}

\author{
Abstract \\ In this article, I argue that urban school reform falters, in part, because of the lack of an \\ organized political constituency among the stakeholders with the most direct interest in \\ school improvement, that is, parents whose children attend urban schools. I examine \\ community organizing as a potential strategy to build such a constituency. Drawing \\ primarily upon extensive fieldwork research, I construct a case study of one of the \\ country’s largest community organizing networks, the Texas Industrial Areas \\ Foundation. I analyze the network’s Alliance Schools initiative to promote school reform \\ in one hundred and twenty public schools in districts across the state. I find that \\ organizing efforts like the IAF, despite important limitations, are beginning to create an \\ external force for change in district policy as well as to collaborate internally with \\ educators to produce change in the practice of education within schools.
}




\section{Building a Political Constituency for Urban School Reform}

Despite great attention to reforming schools in urban districts, significant progress has been slow to come (Payne, 2008). Test scores have risen in some categories, but it remains unclear how much of this increase reflects real learning (Koretz, 2008). Meanwhile, the crisis of urban schooling continues with devastating consequences. Some recent studies suggest that as many as half of all black and Latino students fail to graduate high school on time (Orfield, Losen, Wald, \& Swanson, 2004).

In communities where parents are well organized and politically influential, such poor performance would not likely be maintained. Yet parents in urban communities often do not have the political clout to effect change (Henig, Hula, Orr, \& Pedelescleaux, 1999). Community organizing, meanwhile, has emerged as an important set of efforts that work to engage and build such a constituency among the stakeholders with the most direct interest in school improvement, that is, parents whose children attend schools in low-income communities (Warren, 2005). Perhaps as many as five hundred community organizing groups now work to reform public education in low-income communities across the country, and the field appears to be rapidly growing (Gold, Simon, \& Brown, 2002b; Mediratta \& Fruchter, 2001; Warren, 2010).

In this article, I argue that urban school reform falters, in part, because of the lack of an organized political constituency that demands change and holds school systems accountable for progress. I suggest that strong and sustained progress in school reform may require moving beyond "the four walls of schools" to engage the participation of parents and residents of low-income communities directly in the reform process. I then 
turn to an examination of efforts by community organizing groups to build such a constituency and to make an impact on urban school reform.

\section{The challenges to urban school reform}

Scholars have offered a number of explanations for the failure of urban schools to make and sustain real improvement. First of all, urban school reform tends to be episodic: urban districts adopt a host of rapid reforms that are seldom sustained, a process Frederick Hess (1999) aptly described as "spinning wheels.” Before one reform has time to take hold, the district moves on to the next reform du jour (Farkas, 1992). In a sense, then, district leaders conduct symbolic politics, giving the impression of responding to problems and creating change, but failing to carry through. Clarence Stone and his associates (C. N. Stone, Henig, Jones, \& Pierannunzi, 2001) have argued for the need to build civic alliances that can help create reform initiatives and hold districts accountable to sustaining their implementation. It turns out that these alliances themselves are difficult to organize. Stone, however, notes that even the stronger alliances typically exhibit very weak participation from parents and community-based groups in low-income communities (see also Henig et al., 1999).

Secondly, urban school reform efforts tend to be superficial. Richard Elmore argues that since public schools are loosely coupled systems, change typically occurs at the surface level while the core processes of teaching and learning remain largely unaffected. Even when model practices are identified at one school, they are seldom transferred to others (Elmore, 2000). Once again, urban schools appear to respond to public concern by adopting change initiatives, but they are neither deep nor sustained. In 
response, some scholars have called for a sharp focus on instructional leadership (Elmore, 2000) that is more collaborative (Spillane, 2006) and focused on performance using data (Boudett, City, \& Murnane, 2005). However, in these approaches, the reform processes and their actors remain solidly within the school system and therefore may still lack sufficient incentive to make and sustain change.

Reform initiatives that remain solely within the school may falter because urban schools are weak institutions marred by internal distrust, especially along racial lines (Henig et al., 1999; Payne, 2008). The best-laid plans typically run afoul of divisive school politics as factions fight each other within schools. Even if a school lacks organized factions, teachers can become so atomized and isolated in their classrooms that they lack the ability to cooperate towards shared ends. Lacking a cooperative spirit and trusting relationships in the school community, reform plans falter. In fact, Bryk and Schneider (2002) have shown that schools with strong and trusting relationships have greater capacity to genuinely embrace and effectively implement reform initiatives. A recent study of the 144 inner city public elementary schools in Chicago identified as lowachieving in 1990 that substantially increased their reading test scores, typically to the national average for the Iowa Reading Test, found that "the most consistent feature of these schools is that all adults work as a team to improve education, including the teachers, parents, Local School Council, principal and community agencies” (Designs for Change, 2005, p. ii). Most reform efforts, however, lack such collaboration with organized parents and communities.

Fourth, some scholars have argued that racism directly undermines reform efforts. Theresa Perry (2003), for example, argues that schools as dominant institutions operate 
on the basis of the assumption of black intellectual inferiority. In other words, educators hold racial stereotypes about their low-income students of color. They have low expectations of these students and misinterpret cultural behavior. A school can adopt an improved educational practice, but if teachers fail to believe their low-income students of color can learn and achieve at high levels, their core teaching practice will not change (Oakes \& Rogers, 2005). According to Oakes and Rogers, the only way to challenge and eventually change deeply held cultural beliefs is through the mobilization of marginalized groups in a social movement.

A fifth view describes low-income families with children, particularly in high poverty urban neighborhoods, as a “captured population” (Noguera, 1996, p. 198). Because parents have no real choice but to send their children to local schools, there is little incentive for urban schools to change. Teachers will receive their paychecks even if the school fails to perform well year after year. Accountability through elected school boards appears weak, and that has led to the more recent drive for mayoral control (Henig \& Rich, 2004). NCLB and testing regimes are meant to create an external system of accountability for these schools. But, given the growing teacher shortage, especially in our most troubled schools, most educators remain secure in their jobs despite continued school failure. Given the weaknesses in the internal capacity of urban schools discussed above, it remains unclear how externally-based test accountability will create real and sustained improvements in teaching and learning (Elmore, 2004).

Finally, "within the four walls” school reform may be inadequate because the problems of urban schools lie embedded in system of structural inequality based upon race and poverty. In other words, urban schools often serve communities that are poor, 
segregated, and disempowered. The lack of resources and internal dysfunction of urban schooling is directly tied to post-war urban decline (Anyon, 1997). Put bluntly, what sense does it make to try to reform urban schools while the communities surrounding them continue to decline (Warren, 2005)? Small, incremental improvements in schools will do little to alter the individual life chances of inner city students; real gains are more likely through collective mobilization (Schutz, 2006). In other words, traditional school reform ignores issues of power. In this view, changing schools must be linked to efforts to change broader social structures, which requires political mobilization to connect schools to community revitalization at the local level (Warren, 2005) and government policy at the national level (Anyon, 2005).

Taking the analysis presented above together, it appears that urban school reform falters, in part, due to a lack of political will. Since urban schools operate in captured populations who lack the resources to pursue alternatives (Noguera, 2003), they often get away with symbolic efforts that create the impression of change. Urban schools lack a political constituency of those most affected, parents with children in schools, who can demand real improvement and hold public schools accountable for results over a sustained period of time. In this context, community organizing represents an important strategy to build such a constituency (Rogers, 2006).

However, the analysis presented above also suggests that external demands, even ones made by an organized political constituency, may prove limited if they fail to increase the capacity of schools to change. Organizing efforts, then, must find a way to connect with schools so that change reaches into core processes of teaching and learning. In other words, a political constituency of parents has to become directly engaged within 
schools to help build social capital that can increase the capacity of schools to improve (Warren, 2005). In addition, when inside the school, an engaged group of parents and community members can build face-to-face relationships with school-based educators to more directly hold them accountable for improvement (Mediratta \& Fruchter, 2003).

Building such a political constituency is not easy. Low-income parents typically work long hours and find themselves beset by a range of challenges that make engaging them in political action difficult, from finding adequate housing and health care to dealing with drugs and violence in their neighborhoods. Low-income parents, however, are not uniquely disengaged: direct participation in organized civic and political action has declined across the board in America (Putnam, 2000). But low-income communities lack the resources of their more affluent counterparts and exhibit greater needs. Nevertheless, the main problem may not lie in the individual, passive parent but rather in the lack of opportunity for participation. As Theda Skocpol (2003) has shown, the civic landscape is now skewed towards advocacy organizations that speak for people, rather than involve them directly in civic and political life. Most organizations either provide services to, or advocate for, low-income families; few serve as vehicles for their active participation. The result is a widening inequality in political participation (Schlozman, Page, Verba, \& Fiorina, 2005) and the increasing power of elites in public policy (Hacker, Mettler, \& Pinderhughes, 2005).

Before turning to community organizing, we might consider two better known approaches to engaging the broader public in urban communities. Advocates of familyschool-community partnerships have argued for an inclusive approach to education, where school-based educators involve parents and collaborate with community agencies 
(Cibulka \& Kritek, 1996; Epstein et al., 2002). Although this approach focuses on service delivery, for example in the form of full-service community schools (Dryfoos, 2002), many partnerships do recognize the value of connecting teachers with parents and involving parents in their children’s education (Henderson, Mapp, Johnson, \& Davies, 2007; Warren, 2005). Community organizing shares some features in common with partnerships, and organizing efforts often result in improved programming. Nevertheless, most partnerships represent efforts to get parents to support the school's agenda (Warren, Hong, Rubin, \& Uy, 2009); seldom do they take a political approach to school reform, engaging parents as leaders and collaborators in transforming schools and holding systems accountable for change.

Advocates of civic alliances and collaboratives for systemic change do take a more political approach. They argue that long-term and sustainable school reform requires building a civic and political base amongst a variety of actors and organizations in an urban district (C. N. Stone et al., 2001). These alliances and collaborative typically work in alliance with school district administrations to both contribute to and help sustain systemic reform initiatives like the development of small schools or small learning communities. In some cases Local Education Funds and philanthropic organizations take the lead (Useem, 1999). In others, the business community or local universities gain more prominence. Again, a community organizing approach shares some overlap with collaboratives. In fact, organizing groups sometimes participate in, or even lead alliances for reform as we will see later. Meanwhile, some collaboratives make more serious efforts to engage people at the grassroots level. But the typical collaborative is a rather top-heavy affair made up of elite institutions advocating "for" students and families. In 
fact, in their study of civic alliances Clarence Stone and his associates (2001) found nearly all these collaboratives lacked the organized participation of the people with the strongest self-interest in urban school reform, that is, parents from low-income communities whose children attend the district's schools. Jeff Henig and his associates (1999, p. 189) also found lacking a broad community and parent-based movement in the eleven urban districts they studied, calling this critical absence “the dog that hasn't barked.”

\section{$\underline{\text { Data and Methods }}$}

In the rest of the article, I draw upon my extensive fieldwork research conducted on the Industrial Areas Foundation (IAF) organizing network in Texas between 1993 and 2003. I supplement this data with published accounts of organizing efforts in New York City and elsewhere. In my research in Texas, and as is typical in case study research (Merriam, 1998; Yin, 2003), I employed a combination of data collection methods, including interviews, participant observation and document analysis. I conducted one hundred and fifty-one interviews for this study, including participants in the IAF network, actors who have experience with the network, as well as independent observers. ${ }^{1}$ These semi-structured interviews were designed to reveal organizing processes and outcomes from multiple perspectives.

I conducted observations at a wide variety of IAF activities, including leadership training sessions, meetings of staff organizers, action team meetings, larger public assemblies, direct action events, and organizational leadership meetings. These were designed to see organizing in action, to better understand the role of various kinds of 
participants (e.g. leaders and organizers) and to observe the dynamics in the relationships between various stakeholders (volunteer leaders, paid organizers, allies and the targets of the IAF’s actions). Detailed field notes were taken. I observed seventy meetings in all.

Finally, I collected and examined a variety of documents. Internal IAF

publications (newsletters, leaflets, and budget reports) provided further information about the network's practices. Newspaper articles provided information about the public activities of the network.

I analyzed the interview material, observational field notes and documents using categories derived from analysis of school reform sketched above as well as those that arose inductively from the data. In order to increase the accuracy of the analysis, data sources were "triangulated" by checking wherever possible what people said in interviews against what was observed and what was stated in published accounts. To strengthen the validity of the findings, I looked intentionally for discrepant data (e.g., by interviewing observers who were independent of the IAF and sometimes critical of the network) and alternative interpretations for emerging patterns in the analysis (Maxwell, 1996).

In the next section I present an historical overview of community organizing efforts at school reform. Then, after discussing some published accounts of other education organizing efforts in New York City, I present an analytical case narrative of the Texas IAF constructed from the data I collected. A more extensive analysis of the network can be found in Warren (2001). Due to space limitations, and as is typical in case study presentations, I have not cited the data sources (interviews and observations) for all 
of the specifics in the case history recounted here. These sources are available from the author upon request.

\section{The Turn of Community Organizing to Education Reform}

Community organizing has long distinguished itself by focusing on cultivating participation and leadership by grassroots people in civic participation and political action. Rather than advocating for people, organizing groups seek to engage people directly to work for change in their schools and communities. Organizing groups find their roots in several American movements, from settlement houses to the civil rights and women’s movements (Fisher, 1994). However, they draw most explicitly from the community organizing tradition developed by Saul Alinsky in Chicago in the thirties (Alinsky, 1971; Horwitt, 1989). Alinsky sought to work with institutions that structured community life, like religious congregations, to build leadership and power for working class people. At the same time as CIO unions were organizing workers in industry, Alinsky sought to create organizations through which working people could act to create change in their neighborhoods.

Alinsky’s organizing tradition went through many changes over the years and spawned a variety of styles (Reitzes \& Reitzes, 1987), but its core focus on participation and leadership, if anything, strengthened (Warren, 2001). Moreover, the civil rights movement contributed a new appreciation for the power of faith and of grassroots local action (Morris, 1984; Payne, 1995). As the movements of the sixties declined, organizing groups came to concentrate their work mainly on issues of housing, economic development and neighborhood safety, but seldom schooling. In the nineties, however, in 
recognition of the increasing importance of success in schools to children's life chances, organizing groups began to turn their attention to the crisis in public education in their communities (Warren, 2005). In other words, they have sought to bring to bear their skills in political constituency-building to school reform. Recent research suggests that community organizing groups working for education reform number over two hundred (Gold et al., 2002b; Mediratta \& Fruchter, 2001), with a recent estimate putting the figure at five hundred (Warren, 2010).

\section{Education Organizing in New York}

Initially many organizing groups took the approach of marshalling their base to build the political will to get institutions to meet community demands. This approach followed standard organizing practice as had been applied to community development issues. In other words, most organizing groups had honed their skills in efforts to get city housing authorities to enforce codes, to get banks to end redlining and lend in inner city

neighborhoods, and to get a variety of services improved (Briggs \& Mueller, 1997). This strategy represents a "unilateral” approach to power, where power is understood to be the force to get others to do your bidding (Warren, 2005).

This “power over” approach can create the political will for change in public education. For example, New Settlement Apartments (NSA), a community development corporation, had organized around a variety of housing and neighborhood issues in the South Bronx, a community made infamous as a symbol of urban decline. By the early 1990s it could claim many accomplishments, providing housing for nearly 900 families, and opening playgrounds and community programs. But, according to Eric Zachary and 
shoal olatoya (2001), who have studied NSA's education work closely, NSA affiliated parents began to complain more and more about the struggles their children were having in District 9 schools, perhaps the worst performing in the entire city. ${ }^{2}$ In 1995 NSA formed a Parent Action Committee (PAC) which chose to focus its efforts on PS 64, the local elementary school. The group partnered with the Community Involvement Program at NYU's Institute for Education and Social Policy, which had been supporting education organizing efforts for several years. Program staff brought needed expertise on education issues and in organizing to NSA parents. A turning point came when parents learned that only $17 \%$ of students at PS 64 read at grade level. PAC sought to meet with the principal to discuss what was being done to improve education at the school. They found to their surprise that the principal did not know these statistics but defended the school anyway. He showed no sense of urgency and refused to meet again with PAC, telling them to get involved with the parent association at the school. In response to this rebuff, PAC gathered 1,100 signatures demanding the removal of the principal and organized a number of protest actions. After three years of organizing, the principal was removed and a new principal more open to school change and collaboration with PAC was hired. Tragically, however necessary this campaign proved to be, all of the civic energy expended by the group had no immediate impact on improving education at the school.

Another example from New York City shows the possibility for organizing efforts to create the political will for policy change and to hold school systems accountable for sustained change. New York ACORN, the local chapter of the national ACORN community organizing network, had been involved in a variety of education efforts in the early nineties working predominantly with black and Latino families in some of New 
York’s poorest neighborhoods. According to Elaine Simon, Marcine Pickron-Davis and Chris Brown (2002), who have studied the network closely, these parents had consistently complained about discriminatory treatment they felt their children faced in the schools. ${ }^{3}$ Following the model of audit studies to demonstrate housing discrimination (Yinger, 2001), ACORN organized black and white parents to visit schools to ask for information about gifted and talented programs. Many of the group's minority parent "testers" had trouble getting past security guards to reach the school office to ask for information. In the end, black testers saw educators half as often as white parents who received school tours two and a half times as often as the black parents did. ACORN issued their Secret Apartheid report in 1996 detailing their findings (ACORN, 1996), and the group proceeded to organize protests on racial discrimination. As a result, then Chancellor Rudy Crew drafted new standards for admission to gifted programs and the Department of Education's Office of Civil Rights issued a consent decree to reduce discrimination in informing parents about gifted programs.

ACORN, however, proceeded to monitor the district's practice, finding little real improvement or enforcement of the agreement. The group continued to demand action and moved forward with the next phase of its campaign, issuing Secret Apartheid II (ACORN, 1997). This report showed that the coursework offered at a majority of the middle schools serving black and Latino students did not prepare them to take the entrance exams to the city's selective high schools. After ACORN mobilized parents to a series of actions, Crew eventually agreed to direct $\$ 8$ million in funding to provide 2,000 students with access to the district's Math and Science Institute that would prepare them for the selective exams. By leveraging its neighborhood-based social capital, ACORN 
had succeeded in winning some important reforms to the system, which, although only partially implemented, opened up greater opportunities for children of color.

These are important accomplishments to be sure, but organizing groups realized over time that they were not directly affecting the core of teaching and learning at failing schools. As a result, many groups in the field have turned towards a more collaborative approach to change processes within the school. They have not necessarily abandoned their independent stance or their ability to leverage "unilateral power.” But they have added to that approach a greater emphasis on collaboration, an understanding of "relational power" (Warren, 2005), also referred to as a social reproduction model of power (C. Stone, Doherty, Jones, \& Ross, 1999).

For example, beginning in 2000, New Settlement Apartments and the Bronx chapter of ACORN worked with four other community organizations and the Community Involvement Program at NYU to form the Community Coalition for District 9 (CC9). According to Michael Fabricant (2010), who has studied the coalition closely, the groups decided that, in order to deeply affect school practice, they needed to combine their diverse bases to create greater influence. ${ }^{4}$ CC9 targeted three interrelated issues: improved teacher quality, stronger school leadership, and the creation of schoolcommunity partnerships. In order to focus their efforts, the CC9 groups launched a campaign to provide greater support and mentoring of new teachers. Teacher turnover in District 9 was so high that only about half of teachers in the district's schools had been there more than two years; less than half had five years of teaching experience. In pursuit of this campaign, CC9 followed a twin strategy. CC9 organizers leveraged the groups' bases of parent leaders from their neighborhood work to influence district policy. They 
also partnered directly with ten district schools whose principals were open to a greater role for community collaboration and parent voice in the schools.

During this period, New York's mayor took control of the school system and a new team of Department of Education (DOE) regional superintendents replaced many who had been hostile to community participation. In addition, CC9 reached out to the UFT teacher's union, which had become relatively isolated in its contract negotiations at the time. CC9 offered support to the UFT in exchange for its willingness to join a partnership to develop the new lead teacher program. The program was designed to offer incentives for experienced teachers to come to District 9 schools to become lead teachers; they would receive $\$ 10,000$ in additional pay and 50\% release time to mentor new teachers. Such mentoring would improve the quality of teaching by new teachers and the support they received would make it more likely that they would stay on at the school, reducing turnover.

CC9 developed a core of parent leaders to lead the campaign. It did so through a variety of trainings designed to build parents' understanding of the education policy issues at hand and their ability to carry out a complex organizing campaign. This campaign combined sustained private negotiations with the UFT and the DOE to gain their agreement, along with a large public petitioning effort. By the spring of 2004, CC9 had gathered 10,000 signatures and delivered them to the DOE. Meanwhile, CC9 kept up pressure through letter-writing and strategically organized rallies at DOE headquarters. By the summer of 2004, the DOE and UFT both agreed to adopt the program and victory was declared. Although it is still early, there is some indication that teacher retention has 
already begun to increase at District 9 schools, and test scores have risen strongly at the ten schools with whom CC9 directly partners (Fabricant, 2010).

\section{The Texas IAF and Alliance Schools ${ }^{5}$}

Probably the most ambitious effort to build a political constituency to change the culture of public schooling comes from the Texas Industrial Areas Foundation (IAF) and its Alliance Schools initiative. The Texas IAF is the direct inheritor of Alinsky's tradition, as Alinsky himself formed the IAF in the 1940s. Yet its approach has grown and developed through the leadership of Alinsky-trained Ernesto Cortes and his colleagues who have emphasized stronger relationship-building, more systematic leadership development among members, and a priority on institutional membership in religious congregations (Warren, 2001). While the CC9 campaign directed organizing more centrally towards improving teaching in schools, the Texas IAF's effort was even bolder. It took organizing itself directly into schools through the Alliance Schools initiative.

By the late 1980s, the IAF network in Texas had grown from its flagship organization COPS in San Antonio to include a dozen affiliates across the state, in Austin, Fort Worth, Houston, the Rio Grande Valley, and El Paso with start-ups in Dallas, Beaumont, and Eagle Pass. ${ }^{6}$ Local organizations won funds for infrastructure improvements, affordable housing, and new services in their neighborhoods. The state network cut its teeth winning historic campaigns to bring water and sewer services to colonias (unincorporated areas along the Mexican border) and provide health care for indigent workers. As they improved infrastructure and some services in their 
communities, IAF organizers and leaders increasingly sought to address more difficult issues, ones that could not be solved solely by an infusion of funds. Institutional reform was often necessary, and this task required a longer-term involvement by IAF affiliates and more complex processes of confrontation and collaboration. Education reform arose at the cutting edge of this realization.

In one of the earliest forays of a community organizing group into education work, the network participated in the Texas school funding equalization and reform effort led by Ross Perot in the mid-eighties (Lavine, 1997). During this effort the IAF came to see greater funding as a necessary, but not sufficient, strategy for improving schools. In the IAF's view, the causes of school failure went beyond low funding levels and demanded a program of broader institutional reform that needed to be addressed school by school. This strategy fit well with the IAF's institutional approach. The network had been used to working with member congregations to lead internal organizing efforts to strengthen those institutions as they became engaged in organizing efforts. But, of course, schools were public, not private organizations. Never before had the Texas IAF attempted to reform a public institution so deeply entrenched, and in their view so deeply flawed. School reform would require a long-term, sustained effort. With the official founding of the Texas IAF network in 1990, Cortes saw an opportunity for a statewide initiative in which every affiliate could participate and benefit; this effort became known as the Alliance Schools.

From modest beginnings in the late 1980s, the network’s Alliance Schools initiative grew to include over 120 schools across the state, making it the single largest school reform experiment in the country based upon parent and community engagement. 
Meanwhile, IAF sister organizations in the network spread the model across the Southwest and Southern California. The Alliance Schools initiative has several distinguishing features. Schools in the alliance become institutional members of the local IAF organization. They collaborate with member congregations and receive the services of IAF organizers to help them strengthen their internal capacity for educating children; the schools also receive additional state funds for staff and program development. At the same time, the schools become involved in other issue campaigns of the IAF organizations, so that their participants (teachers, principals, parents, and other adults in the school community) become trained and engaged as political leaders in the broader community. In this process, IAF organizers and local leaders explicitly seek to engage the democratic traditions of American education (Dewey, 1938 [1916]) and activate them for the current realities of low-income communities.

The beginnings of the Alliance Schools initiative can be found in the work of the IAF's affiliate in Fort Worth, Allied Communities of Tarrant (ACT). African American leaders in ACT had long been concerned with the failure of many black youth in Fort Worth district schools. Individual meetings with church members and house meetings with groups of neighborhood residents had consistently raised the issue of poor academic performance and high drop out rates among African American youth. In 1985 Reverend Nehemiah Davis began to talk with other African American ministers in ACT about the possibilities of addressing what they increasingly saw as a crisis in their community. The black ministers asked ACT’s lead organizer at the time, Sr. Mignonne Konecny, to accompany them to meet with business leaders and school officials in the city to see what kind of role ACT might play in revitalizing schools. 
Meanwhile, in the summer of 1985, the school district appointed a new principal, Odessa Ravin, to Morningside Middle School. Morningside was a predominantly black inner city school located in an area from which most of ACT's black churches drew members. Eight-five percent of Morningside students qualified for free or reduced-price lunches. More than half came from single parent families. Morningside students were scoring last among all Fort Worth Independent School District middle schools on tests of educational achievement. Half of the students had failed the writing component of the Texas Educational Assessment of Minimum Skills (TEAMS) test. ${ }^{7}$

Ravin had taught at Morningside many years earlier. As its new principal, she was committed to turning the school around. In fact, she had begun visiting churches herself looking for community support for the school. ${ }^{8}$ But Ravin faced a daunting challenge trying to rebuild such a dysfunctional school. On the night before the new school year began in the fall of 1985, the school's office was firebombed. Ravin spent her first year at Morningside attending to one crisis after another with little opportunity to begin radical changes.

In 1986 Reverend Davis and organizer Konecny began meeting with principal Ravin and they agreed to work together. The Morningside campaign began without a preset reform agenda. Instead, ACT followed the IAF relational organizing strategy of individual meetings to begin the process of building relationships that could lead to action. ACT leaders, along with some Morningside teachers, set out to visit the home of every parent with a child at the school. Through these discussions, ACT leaders sought to determine the needs and concerns of parents and to identify those most interested in 
participating. The stated goal was to get every parent involved in the education of their child.

The meetings identified an important obstacle to parental involvement. Many parents reported feeling isolated from each other and impotent in dealing with the school administration. In response, ACT organized a series of meetings involving fifty to one hundred parents during the first school year. The meetings provided an opportunity for parents to discuss their relationship to the school. According to Davis:

At the meetings, we had facilitators and we trained them. Their role is to keep a dialog going, not to answer questions, to get parents talking to each other. Teachers and principals sit in to listen....We let people vent anger and frustration. That's necessary for healing to take place. After some time, they calm down on the inside and can be constructive. Then the facilitator lists problems and solutions, all from the parents....At the next meeting, the angry parents are often the conciliators. In between time, we try to get them to visit the school. Most parents don't go to school until they're angry. This time their experience is more positive and, at the next meeting, they're positive. ${ }^{9}$

As parents became more positive and empowered, they began to identify specific needs, some of which concerned issues outside of the school. ACT's first campaign involved closing a store that sold alcohol to underage students down the street from Morningside. As parents and school personnel gained confidence and organizing capacity, they turned their attention more directly to educational issues. ACT responded by developing training programs on such issues as how to help a child with homework. 
Consistent parental concerns expressed about unsupervised children during after-school hours led ACT to help parents establish a free after-school program at Morningside featuring sports, arts and academic tutoring. African American churches in ACT developed their own programs, like parent and child recognition ceremonies, to support the school campaign.

The parent organizing effort at Morningside began to demonstrate immediate success. Seven hundred parents attended the fall back-to-school open house after ACT’s first year of organizing. Only forty or so parents had ever shown up previously. Within two years, student scores on the TEAMS achievement test had risen from last among all middle schools in Fort Worth to third place. In 1990, Morningside received the Texas Governor's Excellence Award, and was one of four schools in Texas to win the Carnegie Initiative Award from the Texas Education Agency. ${ }^{10}$

Inspired by the early successes of the ACT effort, Cortes encouraged other Texas IAF affiliates to experiment with school reform efforts. Meanwhile, economic and political developments in the late 1980s helped create a greater opening for a major state initiative by the IAF. First, the oil crisis of the 1980s had sent Texas into a long and deep recession, exacerbated by the savings and loan crisis. Although Texas always had pockets of poverty, the poor were easily overlooked during the period of rapid economic growth in the 1970s. Many assumed poverty was solely the problem of rural Mexican immigrants. Once the recession set in, however, unemployment and poverty grew. Moreover, large Texas cities began to experience a concentration of poverty in their inner cities that devastated communities (Kasarda, 1994). Crime, school failure, and drug abuse emerged as public issues of concern in the state. 
In 1990, Democrat Ann Richards was elected governor of Texas. Richards had already worked closely with the IAF on the colonias issue when she was State Treasurer. Since the Democratic Party itself had a weak organized base in Texas communities, the IAF represented a powerful ally that could support the broader goals of her administration. After her election, Richards appointed former COPS co-chair Sonia Hernandez as the director of education policy in her office. She appointed the reformminded Lionel "Skip” Meno to head the Texas Education Association (TEA), the state’s department of education.

With Meno’s support, IAF leaders lobbied the legislature to pass a pilot Alliance Schools program in 1992, modeled in part on its work at Morningside. The initial Alliance Schools program provided \$10,000 in TEA funding to each of twenty-one schools involved in local IAF efforts. Principals who joined the effort could use the funds to support teaching training and curricular development in their schools. The bill also provided for special waivers so that local schools could by-pass some regulations and establish innovative reforms more quickly. For its part, the IAF would provide professional organizers to engage parents and the broader community in transforming schools and increasing student achievement. It would also take organizing right into schools, working directly with principals and teachers who would become organizational leaders along with parents and community residents. Alliance Schools joined their local IAF organization and emerging school leaders became part of the organization's leadership team.

The Texas IAF proceeded to make an organizational commitment to the Alliance Schools far exceeding anything in its past. Cortes lobbied private foundations for the 
funds to hire new organizers for the local school efforts. Although the lead organizers for local affiliates were prepared to supervise and train school organizers, the effort could not succeed without the new staff. Impressed with the network’s work at Morningside Middle School and elsewhere, the Rockefeller Foundation granted the funds needed to hire education coordinators over a five-year period beginning in $1990 .{ }^{11}$

The new organizers, education coordinators as they were called, went to work, using the IAF's relational organizing strategy to engage parents and other residents of neighborhoods surrounding the Alliance schools. The more successful campaigns drew upon the base already established in local churches as experienced IAF leaders from congregations near the local schools helped engage parents and school staff. The IAF built school campaigns not around issues identified a priori by school reform experts, but rather out of the concerns and interests of local parents. At the Zavala School in a Hispanic neighborhood in Austin, the first campaign sought to establish a health clinic at the elementary school. Some efforts focused on school safety. Meanwhile, school principals used the extra Alliance funds to help teachers develop innovative curricula to reform the structure of schooling. In the predominantly black Roosevelt High School in Dallas, for example, the principal implemented a block-scheduling program.

Through the Alliance Schools, principals, teachers as well as parents all become potential political leaders in Texas IAF organizations and are trained to collaborate with each other. The network uses its strategy of relational meetings, where leaders share their values and concerns in one-to-one focused conversations with each other, to strengthen understanding and trust. This brings parents into active roles in schools, but also brings teachers and principals into action around community concerns, whether the sale of 
alcohol to school children in Fort Worth or later efforts to develop a job training program in Austin.

While local school organizing gave the effort solid roots, the IAF also worked to develop a multi-level collaborative approach to deepen and expand the reform work. The IAF convened a series of statewide leaders meetings on education. Hundreds of local leaders attended a series of meetings in which they read studies and heard presentations from school reform experts. The network drafted a document entitled "The Texas IAF Vision for Public Schools: Communities of Learners” that framed their emerging work. Although professional staff hired by the Texas IAF helped develop the document, teams of local leaders wrote the actual text. Calling for flexibility and experimentation, the document does not commit the network to apply one single strategy for every school but rather hopes to “inspire a thousand strategies.” Nevertheless, the network places itself squarely in the camp of progressive educational innovation, criticizing the mass production model of schooling and calling instead for schools to become communities of learners. According the document (Texas Interfaith Education Fund, 1990, p. 10):

In our vision, the model of a school shifts from efficiency to effectiveness: from that of students as passive learners to that of a community whose members are committed to learning the skills of problem-solving, teaching themselves and others, and collaboration.

Cortes and the IAF began to talk about the need to build a relational culture in schools as a foundation for any significant progress.

Meanwhile, IAF organizers and leaders spent time reading John Dewey and his modern interpreters. Dewey (1915; 1938 [1916]; 1991 [1927]) saw education as a 
democratic project, a critical institution for progressive social change. Schools in his view should be community institutions with multiple connections between learning and community action. IAF organizers and leaders appreciated Dewey’s educational philosophy and agreed with his vision for a participatory civic culture as vital to American culture more broadly. The IAF's self-education effort proved serious and sustained, providing a basis for engaging school personnel around an educational vision deeply rooted in American schooling, even if that vision has languished in the recent period.

The IAF network sponsored large statewide conferences involving up to one thousand parents, teachers and principals from its local school efforts to hear talks by leading scholars and education activists like Howard Gardner, Ted Sizer and James Comer. The IAF sent local organizers and leaders to training programs every summer at James Comer's center for school reform at Yale University; later they went to Project Zero, the Harvard University program directed by Howard Gardner. These outside resources and connections gave legitimacy to local leaders and school personnel struggling to overcome the resistance of district administrators. It also broadened and deepened their perspective on school reform, stimulating new ideas and strengthening programmatic initiatives.

The Alliance Schools program, for example, helped a new ACT organizer, Leonora Friend, and principal Ravin begin a second round of organizing to expand and deepen reform efforts at Morningside Middle School. Ravin admitted that Morningside’s early gains in test scores had come through an emphasis on drilling and memorization. When the school started administering a more difficult test of achievement, the state's 
TASS test, the school's scores were once again below the state average. Ravin drew from the discussions at Alliance School seminars to move instruction towards developing higher order thinking and problem-solving skills among students. ${ }^{12}$ Meanwhile, Friend organized parents to get more involved in instructional issues in the school, to begin to share responsibility with school personnel for the education of their children. ${ }^{13}$

Dennis Shirley (1997) has examined the results of the Alliance School efforts in its first few years. Of the relatively small number of Alliance Schools in existence long enough to assess, the elementary schools demonstrated noticeable gains in standardized test scores, while the middle and high schools demonstrated no clear gains as a group compared to other similar schools. But it may be unrealistic to expect immediate gains to be made through complicated collaborative processes. Moreover, as Shirley (1997, p. 220) argues, “...a host of teachers, parents, administrators, and community leaders credit the Alliance School network with revitalizing their schools and neighborhoods, and test scores hardly provide a comprehensive measure for assessing cognitive development or community improvement.” In fact, the measurable improvements in educational outcomes appear less impressive than the transformation in the culture and practice of schooling created by the Alliance initiative.

The success of the IAF's relational strategy in involving thousands of parents across the state, coupled with some improvements in test scores at Alliance schools, made the Alliance Schools popular and the Texas IAF more respected among state politicians and educators. Meanwhile, the participation of nationally recognized educators strengthened the legitimacy of the reform effort. Each succeeding legislative session approved an expansion of the Alliance Schools program so that by 1996 it 
covered over 100 schools, providing \$50,000 in special funding to each one. In 1999, the legislature approved yet another expansion of the program, increasing funding from $\$ 8$ to $\$ 14$ million, and allowing each school to receive up to $\$ 100,000$ in extra funding.

\section{$\underline{\text { Discussion }}$}

I have been concerned in this article to examine community organizing as a process to build a political constituency capable of addressing the weaknesses in urban school reform. My analysis of these weaknesses suggested the need for organized communities to follow a twin strategy. They need to work "externally" to demand change and hold systems accountable as well as to work "internally" to collaborate with educators to strengthen the internal capacity of schools to improve. ${ }^{14}$ My analysis of the New York City cases also serves to suggest the necessity of a twin strategy; moreover, it shows that some groups have proved capable of using such a strategy to accomplish significant reform in one large section of a very large and politically complex district. The Texas IAF case suggests a twin strategy can be taken both to a larger scale (across many districts) and more deeply into schools as well.

Beyond the Texas and NYC cases, there is growing evidence that other community organizing groups have begun to experiment with building political constituencies capable both of operating in the political environment around schools, to push for change and hold systems accountable to sustain reform, and also of operating to impact the internal workings of individual schools (Gold et al., 2002b; Mediratta et al., 2009). For example, the Logan Square Neighborhood Association organizes parents in eight elementary and middle schools in its Northwest side Chicago neighborhood. 
Among other reforms, the group piloted a Grow Your Own Teacher program that offers free college education leading to bilingual certification to neighborhood parents who commit to taking positions in these schools (Blanc, Brown, Nevarez-La Torre, \& Brown, 2002; Warren, 2005). Chicago ACORN along with LSNA and other groups organized to get the Illinois state legislature to fund an expansion of the pilot to community organizations across the state (Mediratta et al., 2009). Meanwhile, the Oakland Communities Organization spearheaded an effort that got Oakland Unified School District to open forty-eight small schools across the city, helped plan the design of the schools, and now partners with those schools to increase school-community collaboration (Gold, Simon, \& Brown, 2002a; Snyder, 2008). Many other organizing groups around the county have tried a variety of approaches in this combined direction, that is, both inside and outside of schools (Mediratta, 2004; Mediratta \& Fruchter, 2001).

The study of community organizing efforts at urban school reform is a relatively new field. This close examination of one case in Texas, along with examples from New York and other districts, is highly suggestive of the possibilities for organizing to represent an effective strategy for reform. But much more research needs to be done to examine the field and its outcomes. One recent study (Mediratta et al., 2009) showed that organizing efforts can impact student achievement when taken to a sufficient scale in a favorable environment. But we do not know how many organizing groups have had such impact.

Moreover, we need more comparative research to determine what kinds of organizing strategies prove effective in what kinds of contexts. We also need to consider 
the internal capacities organizing groups require to undertake this work (Gold et al., 2002b). The cases discussed here, however, suggest some beginning hypotheses.

\section{$\underline{\text { Context }}$}

In both Texas and NYC, the ability of organizing groups to collaborate with school systems required a willingness on the part of educators to partner with them. In both cases, the opening began with a change in administration, whether at the state level in Texas, the district level in NYC, or the school level at Morningside Middle School in Fort Worth. Community organizing groups, as we saw in both NYC and Texas, often begin to mobilize parents by emphasizing the poor education children are receiving, using test scores often as evidence. This approach may antagonize current school leaders. One can imagine situations where established educational leaders prove willing to collaborate. However, new leaders do not have to take responsibility for past problems or current failures, and that may be why they are more likely to partner. Moreover, new leaders may prove more open to the ideas and initiatives of community organizing groups as they are typically looking to develop their own new initiatives at the beginning of a term. Established leaders may have their own reform agenda, and resent the intrusion of what they may see as non-expert “outsiders” (Cutler, 2000; Fine, 1993).

Pinpointing the kinds of context conducive to organizing is difficult. In fact, the reverse of the pattern just described is also possible. In other words, a new leader can halt a reform initiative that the previous leader established with an organizing group. The community organizing group PACT worked to get the Miami-Dade County Public Schools to adopt direct instruction in a set of schools with which PACT partnered. When 
Rudy Crew took over as district superintendent, he ended the initiative. The organizing efforts of PACT did not prove sufficient to save the program. ${ }^{15}$

The context for organizing efforts is complex and can change over time. The demand to raise test scores has put tremendous pressure on district officials and principals and that can work against collaboration with organizing groups. The rise of high stakes testing regimes in many Texas school districts has threatened to cut off the room for experimentation necessary for organizing efforts at the school level. Even the Texas IAF, one of the strongest organizing networks, has struggled to maintain momentum in this new environment (Shirley \& Evans, 2007). Of course, implementation of testing regimes varies by state and locality. Texas is home to some of the harshest implementation, where some district officials give principals a set number of years to raise test scores and threaten them with dismissal if they fail. In such a climate, creating the space for portfolio assessment, as tried by the Austin IAF affiliate for example, has fallen on deaf ears in school administration.

\section{Internal Capacity}

A twin strategy of outside demand and inside collaboration requires that community organizing groups develop a certain degree of internal capacity. They need the financial resources to pay a sufficient number of professional organizers, expert knowledge to engage in policy development, and a broad enough organizational reach to affect district policy (Gold et al., 2002b; Mediratta et al., 2009). New, small or isolated groups typically lack these kinds of capacity. So it is likely that the larger and more wellestablished organizing groups will be the ones to undertake education reform at this level. 
Even so, organizing groups appear to use different strategies and arrangements to build this capacity. In Texas, the IAF had a broad organizational reach within its network. Its local affiliates operated district-wide and were connected across the state. In NYC, the smaller, independent groups solved the problem by working together in the CC9 coalition. The Texas IAF proved able to build expert knowledge internally by bringing in experts to consult with and train local leaders. The CC9 coalition took a slightly different course. It formed a partnership with the Community Involvement Program then at NYU, which provided expert knowledge for the reform effort.

Both the Texas IAF and the CC9 coalition had to raise significant funds from private foundations to hire organizers to pursue education reform. In contrast to the high demand for capacity required, we must realize that the resources generally available for education organizing are low. These funds come from a combination of member dues and private foundations; they appear meager in comparison to the undertaking at hand. One survey found that the median annual budget of faith-based organizing groups, which are of a size typical of the broader field, is only about $\$ 150,000$ (Warren \& Wood, 2001). Some larger groups do have more sizeable budgets, up to a million dollars annually (Gold et al., 2002b); but even for these larger groups education work represents just one part of that budget. Groups typically have only a few organizers devoted to education organizing.

The community organizing field is also highly fragmented. Its strength lies in its local base and sometimes in its state level reach. But there are few networks that operate at the national level. Some networks have begun to experiment with national level work on healthcare reform, but not around education issues (Whitman, 2006; Wood, 2007). 
Locally based collaborations across organizations are becoming a bit more common as in the South Bronx and Chicago cases. But they still remain rare as groups compete with each other for turf. The number of intermediaries like the Community Involvement Program at the Annenberg Institute (formerly at NYU) is growing, but still remains small. In the vast majority of cities, community organizing groups lack connections to partners who can readily provide expertise.

\section{Conclusion}

Probably the biggest challenge organizing groups face lies in finding a way to influence deeply the core processes of teaching and learning at the school level over a sustained period of time. Collaborations between organizing groups and educators appear important to influence education in that way; and these collaborations require a favorable context of willing educators and organizing groups with relatively high internal capacity. The Grow Your Own Teacher program in Chicago and the teacher leadership program in the Bronx show the potential to begin to impact core processes of teaching; both represent collaborations involving a number of organizing groups. The Texas IAF represents an even more ambitious effort to take organizing right into the institution of the school, and it has the weight of one of the largest and most sophisticated networks behind it. The work seems promising, but it is unclear how deep and broad internal reform will go and how long it can be sustained.

The IAF recognizes that it cannot be the job of community organizers and parents directly to transform instruction; that remains the province of professional educators. What organizing can do is help generate an internal consensus and will to improve on the 
part of educators. Organizing also can help build trust and social capital throughout the whole school community to expand the capacity of schools to change (Bryk \& Schneider, 2002). In addition organizing can increase face-to-face relational accountability in the school (Mediratta \& Fruchter, 2003). These relationships can begin to change stereotypes between teachers and families (Warren et al., 2009), and they can offer a more immediate accountability for school improvement to an organized and educated parent force in the school (Rogers, 2006). If organizing succeeds in this way, it should contribute to improved teaching and learning. Indeed, there is some evidence that the most sophisticated and large-scale organizing efforts like those of the IAF have begun to impact student achievement (Mediratta et al., 2009).

The challenges facing urban school reform are great. Community organizing does not represent a "silver bullet" to solve these problems alone. But, particularly when they ally with other reform agents, organizing groups have begun to show the potential to organize a political constituency to build the political will for change, to contribute to increasing the capacity of schools to change and to hold systems accountable to improve the education provided to children in our urban communities. 


\section{$\underline{\text { References }}$}

ACORN. (1996). Secret apartheid: A report on racial discrimination against black and Latino parents and children in the New York City public schools. New York: ACORN.

ACORN. (1997). Secret apartheid II: Race, regents, and resources. New York: ACORN.

Alinsky, S. D. (1971). Rules for radicals: A practical primer for realistic radicals. New York: Random House.

Anyon, J. (1997). Ghetto schooling: A political economy of urban educational reform. New York: Teachers College Press.

Anyon, J. (2005). Radical possibilities: Public policy, urban education, and a new social movement. New York: Routledge.

Blanc, S., Brown, J., Nevarez-La Torre, A., \& Brown, C. (2002). Case Study: Logan Square Neighborhood Association. Chicago: Cross City Campaign for Urban School Reform.

Boudett, K. P., City, E. A., \& Murnane, R. J. (2005). Data wise: A step-by-step guide to using assessment results to improve teaching and learning. Cambridge: Harvard Education Press.

Briggs, X. d. S., \& Mueller, E. J. (1997). From neighborhood to community: Evidence on the social effects of community development. New York: Community Development Research Center, New School for Social Research.

Bryk, A., \& Schneider, B. (2002). Trust in schools: A core resource for improvement. New York: Russell Sage Foundation Press.

Cibulka, J. G., \& Kritek, W. J. (Eds.). (1996). Coordination among schools, families, and communities: Prospects for educational reform. Albany: State University of New York Press.

Cutler, W. W., III. (2000). Parents and schools: The 150-year struggle for control in American education. Chicago: University of Chicago Press.

Designs for Change. (2005). The big picture: School initiated reforms, centrally initiated reforms, and elementary school achievement in Chicago (1990-2005). Chicago: Designs for Change.

Dewey, J. (1915). The school and society. Chicago: University of Chicago Press.

Dewey, J. (1938 [1916]). Democracy and education: An introduction to the philosophy of education. New York: MacMillan.

Dewey, J. (1991 [1927]). The public and its problems. Athens: Swallow Press, Ohio University Press.

Dingerson, L., \& Levner, A. (2005). A true Bronx tale: How parents \& teachers joined forces to improve teacher quality. Portland: Grantmakers for Education.

Dryfoos, J. (2002). Full-service community schools: Creating new institutions. Phi Delta Kappan, 83(5), 393-399.

Elmore, R. F. (2000). Building a new structure for school leadership. Washington, DC: Albert Shanker Institute.

Elmore, R. F. (2004). School reform from the inside out: Policy, practice, and performance. Cambridge: Harvard Education Press. 
Epstein, J. L., Sanders, M. G., Simon, B. S., Salinas, K. C., Jansorn, N. R., \& Van Voorhis, F. L. (2002). School, family and community partnerships: Your handbook for action (2nd ed.). Thousand Oaks, CA: Corwin Press.

Fabricant, M. (2010). Organizing for educational justice: The campaign for public school reform in the South Bronx. Minneapolis: University of Minnesota Press.

Farkas, S. (1992). Education reform: The players and the politics. New York: The Public Agenda Foundation.

Fine, M. (1993). [Ap]parent involvement: Reflections on parents, power and urban public schools. Teachers College Record, 94(4), 682-710.

Fisher, R. (1994). Let the people decide: Neighborhood organizing in America (Updated ed.). New York: Twayne Publishers.

Gold, E., Simon, E., \& Brown, C. (2002a). Case Study: Oakland Community Organizations. Chicago: Cross City Campaign for Urban School Reform.

Gold, E., Simon, E., \& Brown, C. (2002b). Successful community organizing for school reform. Chicago: Cross City Campaign for Urban School Reform.

Hacker, J., Mettler, S., \& Pinderhughes, D. (2005). Inequality and public policy. In L. R. Jacobs \& T. Skocpol (Eds.), Inequality and American democracy: What we know and what we need to learn (pp. 156-213). New York: Russell Sage Foundation Press.

Henderson, A. T., Mapp, K. L., Johnson, V. R., \& Davies, D. (2007). Beyond the bake sale: The essential guide to family-school partnerships. New York: The New Press.

Henig, J. R., Hula, R. C., Orr, M., \& Pedelescleaux, D. S. (1999). The color of school reform: Race, politics and the challenge of urban education. Princeton: Princeton University Press.

Henig, J. R., \& Rich, W. C. (2004). Mayors in the middle: Politics, race, and mayoral control of urban schools. Princeton: Princeton University Press.

Hess, F. M. (1999). Spinning wheels: The politics of urban school reform. Washington, DC: Brookings Institution Press.

Horwitt, S. D. (1989). Let them call me rebel: Saul Alinsky, his life and legacy. New York: Knopf.

Kasarda, J. D. (Ed.). (1994). Cities as places where people live and work: Urban change and neighborhood distress. New York: W. W. Norton.

Koretz, D. (2008). Measuring up: What educational testing really tells us. Cambridge: Harvard University Press.

Lavine, R. (1997). School finance reform in Texas, 1983-1995. In R. H. Wilson (Ed.), Public policy and community: Activism and governance in Texas (pp. 119-165). Austin: University of Texas Press.

Maxwell, J. A. (1996). Qualitative research design. Thousand Oaks, CA: Sage.

Mediratta, K. (2004). Constituents of change: Community organizations and public education reform. New York: Institute for Education and Social Policy, New York University.

Mediratta, K., \& Fruchter, N. (2003). From governance to accountability: Building relationships that make schools work. New York: Institute for Education and Social Policy, New York University. 
Mediratta, K., \& Fruchter, N. ( 2001). Mapping the field of organizing for school improvement. New York: Institute for Education and Social Policy, New York University.

Mediratta, K., Shah, S., \& McAlister, S. (2009). Community organizing for stronger schools: Strategies and successes. Cambridge: Harvard Education Press.

Merriam, S. B. (1998). Qualitative research and case study applications in education. San Francisco: Jossey-Bass.

Morris, A. D. (1984). The origins of the Civil Rights Movement: Black communities organizing for change. New York: Free Press.

Noguera, P. (1996). Confronting the urban in urban school reform. Urban Review, 28(1), $1-27$.

Noguera, P. (2003). City schools and the American dream: Reclaiming the promise of public education. New York: Teachers College Pres.

Oakes, J., \& Rogers, J. (2005). Learning power: Organizing for education and justice. New York: Teachers College Press.

Orfield, G., Losen, D., Wald, J., \& Swanson, C. B. (2004). Losing our future: How minority youth are being left behind by the graduation rate crisis. Cambridge, MA: The Civil Rights Project at Harvard University.

Payne, C. M. (1995). I've got the light of freedom: The organizing tradition and the Mississippi freedom struggle. Berkeley: University of California Press.

Payne, C. M. (2008). So much reform, so little change: The persistence of failure in urban schools. Cambridge: Harvard Educational Publishing Group.

Perry, T. (2003). Up from the parched earth: Toward a theory of African-American achievement. In T. Perry, C. Steele \& A. Hilliard III (Eds.), Young, gifted and black: Promoting high achievement among African-American students. Boston: Beacon Press.

Putnam, R. D. (2000). Bowling alone: The collapse and revival of American community. New York: Simon \& Schuster.

Reitzes, D. C., \& Reitzes, D. C. (1987). The Alinsky legacy: Alive and kicking. Greenwood, CT: JAI Press.

Rogers, J. (2006). Forces of accountability? The power of poor parents in NCLB. Harvard Educational Review, 76(4), 611-641.

Schlozman, K. L., Page, B. I., Verba, S., \& Fiorina, M. P. (2005). Inequalities of political voice. In L. R. Jacobs \& T. Skocpol (Eds.), Inequality and American democracy: What we know and what we need to learn (pp. 19-87). New York: Russell Sage Foundation Press.

Schutz, A. (2006). Home is a prison in the global city: The tragic failure of school-based community engagement strategies. Review of Educational Research, 76(4), 691743.

Shirley, D. (1997). Community organizing for urban school reform. Austin: University of Texas Press.

Shirley, D. (2002). Valley Interfaith and school reform. Austin: University of Texas Press.

Shirley, D., \& Evans, M. (2007). Community organizing and No Child Left Behind. In M. Orr (Ed.), Transforming the city: Community organizing and the challenge of political change. Lawrence: University Press of Kansas. 
Simon, E., \& Gold, E. (2002). Case Study: Austin Interfaith. Chicago: Cross City Campaign for Urban School Reform.

Simon, E., Pickron-Davis, M., \& Brown, C. (2002). Case Study: New York ACORN. Chicago: Cross City Campaign for Urban School Reform.

Skocpol, T. (2003). Diminished democracy: From membership to management in American civic life. Norman: University of Oklahoma Press.

Snyder, R. (2008). Faith-based organizing for youth: One organization's district campaign for small-schools policy. New Directions for Youth Development(117), 93-107.

Spillane, J. P. (2006). Distributed leadership. San Francisco: Jossey-Bass.

Stone, C., Doherty, K., Jones, C., \& Ross, T. (1999). Schools and disadvantaged neighborhoods: The community development challenge. In R. F. Ferguson \& W. T. Dickens (Eds.), Urban problems and community development (pp. 339 - 380). Washington D.C.: Brookings Institution Press.

Stone, C. N., Henig, J. R., Jones, B. D., \& Pierannunzi, C. (2001). Building civic capacity: The politics of reforming urban schools. Lawrence: University Press of Kansas.

Texas Interfaith Education Fund. (1990). The Texas I.A.F. vision for public schools: Communities of learners. Austin: Texas Interfaith Education Fund.

Useem, E. (1999). From the margins to the center: A look at the work of local education funds in seventeen communities (No. 1). Washington, DC: Public Education Network.

Warren, M. R. (2001). Dry bones rattling: Community building to revitalize American democracy. Princeton: Princeton University Press.

Warren, M. R. (2005). Communities and schools: A new view of urban education reform. Harvard Educational Review, 75(2), 133-173.

Warren, M. R. (2010). Community organizing for education reform. In M. Orr \& J. Rogers (Eds.), Public engagement for public education. Palo Alto: Stanford University Press.

Warren, M. R., Hong, S., Rubin, C. H., \& Uy, P. S. (2009). Beyond the bake sale: A community-based, relational approach to parent engagement in schools. Teachers College Record, 111(9), 2209-2254.

Warren, M. R., \& Wood, R. L. (2001). Faith based community organizing: The state of the field. Jericho, NY: Interfaith Funders.

Whitman, G. (2006). Beyond advocacy: The history \& vision of the PICO network. Social Policy, 37(2), 50-59.

Wood, R. L. (2007). Higher power: Strategic capacity for state and national organizing. In M. Orr (Ed.), Transforming the city: Community organizing and the challenge of political change (pp. 162-192). Lawrence: University Press of Kansas.

Yin, R. K. (2003). Case study research: Design and methods. Thousand Oaks: Sage Publications.

Yinger, J. (2001). Measuring racial discrimination with fair housing audits: Caught in the act. American Economic Review, 76(5), 881-893.

Zachary, E., \& olatoya, s. (2001). Community organizing for school improvement in the South Bronx. New York: Institute for Education \& Social Policy of the NYU School of Education. 
${ }^{1}$ I interviewed 80 IAF volunteer leaders, including parents and educators, 35 professional organizers, and 36 nonparticipant political, community and educational leaders.

${ }^{2}$ This account draws from Zachary and olatoya (2001).

3 This summary is based on Simon, Pickron-Davis and Brown (2002). New York ACORN's work on education is long-standing and also includes pressuring the school district to open several new schools, which the group sponsors. For a history of the early years of ACORN, see Delgado (1986).

${ }^{4}$ This account of CC9 draws from Fabricant (2010). See also Dingerson and Levner (2005).

${ }^{5}$ This account draws from the author's own research as described in Warren (2001). For a broader discussion of the Texas IAF, see Warren (2001); for further treatment of the network's education organizing see Shirley (1997; 2002) and Simon and Gold (2002).

${ }^{6}$ See Warren (2001, chapter 3) on the growth and development of the Texas IAF network. 7 Dennis Shirley (1997) discusses ACT’s campaign at Morningside in detail as part of his book length study of the Alliance Schools. This account draws in part from Shirley's study as well as the author's own research.

${ }^{8}$ Author’s interview with Odessa Ravin, 24 August 1993, Fort Worth, TX.

${ }^{9}$ Author's interview with Reverend Nehemiah Davis, 8 June 1993, Fort Worth, TX.

${ }^{10}$ Fort Worth Star-Telegram December 3, 1988 p. 1A and September 20, 1992 p. 1F.

${ }^{11}$ After the Rockefeller Foundation grant ended in 1995, the Texas IAF succeeded in gaining funding for education coordinators from a variety of foundations, including the Ford and Charles Stewart Mott Foundations.

${ }^{12}$ Author’s interview with Odessa Ravin, 24 August 1993, Fort Worth, TX.

${ }^{13}$ Author's interview with Leonora Friend, 30 August 1993, Fort Worth, TX.

${ }^{14}$ For a similar discussion of some of these issues, see Mediratta, Shah, \& McAlister (2009).

${ }^{15}$ See the 2005 Annual Report of Miami PACT available at http://www.miamipact.org/news/pactannual2005.pdf. 